ISSN 0258-7122

Bangladesh J. Agril. Res. 37(3): 493-503, September 2012

\title{
CORRELATION AND PATH COEFFICIENT ANALYSIS OF MANGO (Mangifera indica L.)
}

\author{
D. A.N. MAJUMDER ${ }^{1}$, L. HASSAN ${ }^{2}$, M.A. RAHIM ${ }^{3}$ AND M. A. KABIR ${ }^{4}$
}

\begin{abstract}
Sixty diverse genotypes of mango were selected from the Germplasm Centre of BAU during December 2007-August 2009 to determine the genotypic and phenotypic correlation along with their direct and indirect effects through path coefficients analysis in mango as to estimate the contribution of most important characters towards yield. It appeared that in most of the cases, the genotypic correlation values were higher than their corresponding phenotypic values. This suggests that there were strong inherent relationship between the traits. Percent flowering shoot had significant positive correlation with inflorescence per shoot, percent perfect flower, percent initial fruit set, number of fruits per plant and fruit weight both at phenotypic and genotypic levels. Fruit yield is determined by some components. The residual effects of genetic and phenotypic path analysis were 0.209 and 0.385 , respectively, revealed higher genetic variability and also proved lower percent of environmental influence on the selected ten characters. In genotypic path analysis, number of fruits per plant had the highest positive direct effect (0.899) on yield. Higher positive direct effects were also observed for the characters inflorescence per shoot (0.539), percent perfect flower (0.816), and percent initial fruit set (0.292), and fruit weight (0.324). Leaf area, percent flowering shoot, number of fruits per plant, and fruit length showed negative direct effects towards yield. In phenotypic path analysis, except percent flowering, shoot per plant and fruit length and other characters also exhibited similar trend on yield as genotypic path coefficient. In combination with correlation coefficient and path analysis, it was found that number of fruits per plant and percent perfect flower gave significant positive correlation coefficients with yield and also produce the high positive direct effect. Thus, it was clear that plant height, inflorescence per shoot, percent perfect flower, percent initial fruit set per inflorescence, and fruit weight are the major component of fruit yield in mango.
\end{abstract}

Keywards: Mango (Mangifera indica L.), correlation, path coefficients studies.

\section{Introduction}

The adequate knowledge of association between yield and its contributing traits has a great importance in plant breeding. For any crop, to setup a suitable

\footnotetext{
${ }^{1}$ Manager, Plant Biotechnology Laboratory, BRAC Agricultural Research and Development Centre, Gazipur, ${ }^{2}$ Professor Dept. of Genetics and Plant Breeding, Bangladesh Agricultural University (BAU), Mymensingh, ${ }^{3}$ Professor Dept of Horticulture, BAU, Mymensingh, ${ }^{4}$ Associate Professor, Hajee Mohammad Danesh Science \& Technology University (HMDSTU), Dinajpur-5200, Bangladesh.
} 
breeding programme, information about interrelationship among and between yield contributing characters is necessary. Correlation and the path coefficient analysis would provide a true picture of genetic association among different traits (Bhatt, 1973).

Correlation in combination with path coefficient analysis quantifies the direct and indirect contribution of one character upon another (Dewey and Lu, 1959). The concept of path analysis was originally developed by Wright in 1921, but the technique was first used for plant selection by Dewey and $\mathrm{Lu}$ in 1959. Path coefficient analysis is simply a standardized partial regression coefficient which splits the correlation coefficient into the measures of direct and indirect effects. Grafius (1959) suggested that there may not be only one gene for yield per se, rather for various components, the multiplicative interaction of many genes result in the yield. Hence, the knowledge of correlation between yield and component characters and among the component characters themselves is essential for a rational and directed improvement of yield (Rao et al., 2004). Path analysis help in determining yield contributing characters and thus is useful in indirect selection. The correlation along with path analysis would give a better appreciation of cause and effect relationship between pairs of character. Knowledge of correlations, if accompanied by the understanding of the magnitude of contribution (direct and indirect) of each component character to the final make up of the fruit yield, the criteria formulated would be effective in selecting the genotypes and using themselves in the crop improvement programme. Therefore, the present study was undertaken to determine the genotypic and phenotypic correlations along with their direct and indirect effects through path coefficient analysis in mango to determine the contribution of most important characters towards yield.

\section{Materials and Method}

Sixty mango genotypes of mango were selected and evaluated based on genetic diversity at Germplasm Center of BAU during December 2007 to August 2009. The experiment was laid out in RCB design with three replications for phenotypic evaluation. The distance from plant to plant was $5 \mathrm{~m}$ and row to row was $5 \mathrm{~m}$. Data were recorded on yield and different yield contributing characters. TSS was recorded with the help of hand refractometer. Genotypic and phenotypic coefficient of variation was calculated for all the quantitative characters (Singh and Chaudhury, 1985). The recommended NPK fertilizer doses and cultural practices along with plant protection measures were followed to raise an ideal crop.

The fruits were harvested at mature stage. Five plants were selected for 10 quantitative traits such as plant height, leaf area, percent flowering shoot, inflorescence/ shoot, percent perfect flower, fruit set/inflorescence, number of 
fruits/plant, fruit weight, fruit length, fruit yield/plant. The collected data were subjected for analyzing Phenotypic (P) and Genotypic correlation coefficient among various pairs of 10 characters of 60 diverse genotypes.

\section{Estimation of correlation}

Genotypic and phenotypic correlation coefficient was estimated according to Prasad and Rao (1989).

\section{Estimation of path co-efficient}

Using genotypic and phenotypic correlation values, path co-efficient analysis was done following the procedure of Dewey and $\mathrm{Lu}$ (1959). In path analysis, correlation co-efficient is partitioned into direct and indirect effects of independent variable on the dependent variable.

\section{Results and Discussion}

Correlation among different agronomic and morphological characters is an important aspect for better planning of selection programs and is also helpful in determining the components of complex trait like yield. But the correlation alone can not prove the exact picture of the relative importance of direct and indirect influences of each of the component characters towards yield. So, the character association is further analyzed through path coefficient. The adequate knowledge of interrelationship among various traits and the practices of unilateral selection for agronomic traits frequently end up in retrograde or less than an optimum result in plant breeding (Bhatt, 1973). The relationship between yield and its components may be due to genetic linkage, pleiotrophy or developmental causes. The correlation and path analysis studies are important assets to the breeder; especially in case of fruit crop like mango, and citrus, where in quantity and quality both are important. The information on the nature and magnitude of variability and correlation in a population owing to genetic and non-genetic factor is one of the prerequisites in any hybridization programme for selecting parents with desirable characters. In present investigation, the correlation between yield and yield contributing characters was measured and discussed.

\section{Correlation between yield and yield contributing characters}

In selection process for crop improvement, knowledge of association of various characters is the most important tool (Desai et al., 1994). The genotypic and phenotypic correlation coefficients were analyzed and presented in Table 1. It appears that in most of the cases the genotypic correlation values were higher than their corresponding phenotypic values. This suggests that there were strong inherent relationship between the traits. The results showed that yield was positively and significantly correlated with plant height, percent flowering shoot, 
Table 1. Genotypic and phenotypic correlation co-efficient between yield and yield contributing characters in mango.

\begin{tabular}{|c|c|c|c|c|c|c|c|c|c|}
\hline Characters & $\begin{array}{c}\text { Leaf } \\
\text { area }\end{array}$ & $\begin{array}{c}\text { \% Flowering } \\
\text { shoot }\end{array}$ & $\begin{array}{l}\text { Inflorescence/ } \\
\text { shoot }\end{array}$ & $\begin{array}{c}\% \text { Perfect } \\
\text { flower }\end{array}$ & $\begin{array}{l}\text { Fruit set/ } \\
\text { inflorescence }\end{array}$ & $\begin{array}{l}\text { No. of fruits/ } \\
\text { inflorescence }\end{array}$ & Fruit wt & $\begin{array}{c}\text { Fruit } \\
\text { length }\end{array}$ & $\begin{array}{l}\text { Fruit yield/ } \\
\text { plant }\end{array}$ \\
\hline Plant height & $\begin{array}{l}0.227 \\
0.195\end{array}$ & $\begin{array}{l}0.490^{* *} \\
0.585^{* *}\end{array}$ & $\begin{array}{l}-0.088 \\
-0.067\end{array}$ & $\begin{array}{c}-0.019 \\
0.003\end{array}$ & $\begin{array}{l}-0.016 \\
-0.013\end{array}$ & $\begin{array}{l}0.295^{*} \\
0.248^{*}\end{array}$ & $\begin{array}{l}0.048 \\
0.045\end{array}$ & $\begin{array}{l}0.417^{* *} \\
0.268^{*}\end{array}$ & $\begin{array}{l}0.580 * * \\
0.598 * *\end{array}$ \\
\hline Leaf area & & $\begin{array}{l}0.426^{* *} \\
0.344^{* *}\end{array}$ & $\begin{array}{l}0.130 \\
0.085\end{array}$ & $\begin{array}{c}0.290^{*} \\
0.221\end{array}$ & $\begin{array}{l}0.219 \\
0.152\end{array}$ & $\begin{array}{l}0.014 \\
0.006\end{array}$ & $\begin{array}{l}0.211 \\
0.129\end{array}$ & $\begin{array}{l}0.027 \\
0.058\end{array}$ & $\begin{array}{l}0.150 \\
0.143\end{array}$ \\
\hline \% Flowering shoot & & & $\begin{array}{l}0.383^{* *} \\
0.370^{* *}\end{array}$ & $\begin{array}{l}0.299^{*} \\
0.258^{*}\end{array}$ & $\begin{array}{l}0.275^{*} \\
0.254^{*}\end{array}$ & $\begin{array}{l}0.310^{*} \\
0.277^{*}\end{array}$ & $\begin{array}{l}0.325^{*} \\
0.285^{*}\end{array}$ & $\begin{array}{l}0.107 \\
0.052\end{array}$ & $\begin{array}{l}0.354^{* *} \\
0.335^{* *}\end{array}$ \\
\hline $\begin{array}{l}\text { Inflorescence/ } \\
\text { shoot }\end{array}$ & & & & $\begin{array}{l}0.155 \\
0.155\end{array}$ & $\begin{array}{l}0.299^{*} \\
0.274^{*}\end{array}$ & $\begin{array}{l}0.162 \\
0.166\end{array}$ & $\begin{array}{l}0.121 \\
0.113\end{array}$ & $\begin{array}{l}0.093 \\
0.044\end{array}$ & $\begin{array}{l}0.286^{*} \\
0.272^{*}\end{array}$ \\
\hline \%Perfect flower & & & & & $\begin{array}{l}0.208 \\
0.177\end{array}$ & $\begin{array}{l}0.438^{* *} \\
0.339 * *\end{array}$ & $\begin{array}{l}0.176 \\
0.150\end{array}$ & $\begin{array}{l}0.237 \\
0.188\end{array}$ & $\begin{array}{l}0.487 * * \\
0.400^{* *}\end{array}$ \\
\hline $\begin{array}{l}\text { Fruit } \\
\text { set/inflorescence }\end{array}$ & & & & & & $\begin{array}{l}0.178 \\
0.156\end{array}$ & $\begin{array}{l}0.017 \\
0.014\end{array}$ & $\begin{array}{l}0.152 \\
0.118\end{array}$ & $\begin{array}{l}0.233 \\
0.216\end{array}$ \\
\hline No. of fruits/plant & & & & & & & $\begin{array}{l}-0.017 \\
-0.016\end{array}$ & $\begin{array}{l}-0.155 \\
-0.112\end{array}$ & $\begin{array}{l}0.586^{* *} \\
0.551^{* *}\end{array}$ \\
\hline Fruit weight & & & & & & & & $\begin{array}{l}0.095 \\
0.084\end{array}$ & $\begin{array}{l}0.262 \\
0.228\end{array}$ \\
\hline Fruit length & & & & & & & & & $\begin{array}{l}0.226 \\
0.179\end{array}$ \\
\hline
\end{tabular}

df $=60-2=58 ;$ r0.05 = 0.255, 
inflorescence per shoot, percent perfect flower, number of fruits per plant both at genotypic and phenotypic levels, but it was positive and not significantly correlated in case of leaf area, initial fruit set per inflorescence, fruit weight and fruit length. Genotypic correlation coefficient revealed that plant height had significant and positive correlation with percent flowering shoot, number of fruits per plant and length of fruit, the phenotypic correlation coefficient also revealed the similar result. The trait had positive but insignificant correlation with leaf area and fruit weight both genotypic and phenotypic level. Negative and insignificant correlation was observed for this character with inflorescence per shoot, percent perfect flower and percent initial fruit set per inflorescence in both level. In case of leaf area, highly positive significant correlation was observed with percent flowering shoot genotypically and phenotypically. This trait had significant positive genotypic correlation with percent perfect flower, but phenotypic correlation revealed positive but insignificant correlation. Leaf area had positive but insignificant correlation with inflorescence per shoot, percent initial fruit set per inflorescence, number of fruits per plant, fruit weight and length of fruit at both level (Table1).

Percent flowering shoot had significant positive correlation with inflorescence per shoot, percent perfect flower, percent initial fruit set, number of fruits per plant and fruit weight both at phenotypic and genotypic levels. Genotypic and phenotypic correlation coefficient revealed that percent perfect flower had highly positive significant correlation with number of fruits per plant.

Number of fruits per plant had negative and insignificant correlation with fruit weight and fruit length at both the levels. Fruit weight had positive but insignificant correlation with fruit length. It was observed that number of seeds per fruit had significant positive correlation with diameter of fruit and average weight of fruit in both levels.

\section{Path coefficient analysis for yield and yield contributing characters}

Significant genetic correlation coefficient between two characters does not always indicate presence of linkage between them. Two characters having a common physiological or biochemical chain may also show such genetic correlation (Hohenboken, 1985). This particularly true for fruit yield in mango, which is determined by some components. Relationship of this character with their components such as plant height, leaf area, percent flowering shoot, inflorescence per shoot, percent perfect flower, percent initial fruit set per inflorescence, number of fruits per plant, fruit weight and fruit length can be explained as physiological and developmental traits. In order to find out a clear picture of the relationship between fruit yield and their components, path analysis study was done at genetic and phenotypic level. This allows the partitioning of the correlations between yield and its components into direct and indirect effects. 
Genotypic and phenotypic correlation values were used to compute path analysis. The residual effects of genetic and phanotypic path analysis were 0.209 and 0.385 , respectively, revealed higher genetic variability and also proved lower percent of environmental influence on the selected ten characters of mango. Direct and indirect effects of different yield contributing characters toward yield of mango for both genotypic and phenotypic levels have been presented in Table 2 and Table 3, respectively.

From path coefficient analysis, it was observed that plant height had highly positive direct effect on yield per plant both genotypic (0.899) and phenotypic (0.998) level. This trait had negative genotypic indirect effect on yield via leaf area, percent flowering shoot, inflorescence per shoot, percent initial fruit set per inflorescence, percent perfect flower and number of fruits per plant. On the other hand, positive indirect effects on yield were observed via fruit length and fruit weight. The character leaf area had high negative direct effect on yield at genotypic level $(-0.274)$ and low positive direct effect at phenotypic level (0.010). This trait exerted positive indirect effect via plant height, inflorescence per shoot, percent perfect flower, and percent initial fruit set per inflorescence, number of fruits per plant and fruit weight. Leaf area had also negative indirect effect on yield via percent flowering shoot and fruit length. (Table 2 and 3).

In the path analysis, it was observed that percent flowering shoot had high and negative direct effect on yield at genotypic (-0.704) level (Table 2) as well as at phenotypic (-0.705) level (Table 3). However, the character had indirect positive contribution to fruit yield through all the important yield contributing characters except leaf area and fruit length, which had very less indirect negative effect towards yield.

Inflorescence per shoot had highly positive direct effect on yield and highly positive indirect effect on yield via percent perfect flower, percent initial fruit set per inflorescence, number of fruits per plant and fruit weight. Inflorescence per shoot also showed negative indirect effect through plant height, leaf area, percent flowering shoot and fruit length on yield.

Percent perfect flower had high positive direct effect on yield at genotypic (0.816) and phenotypic (0.377) levels. This character exerted high positive indirect effect through inflorescence per shoot, percent initial fruit set per plant, number of fruits per plant and fruit weight. This trait had negative indirect effect via leaf area, percent flowering shoot, and fruit length. (Table 2 and 3).

The character percent initial fruit set per plant had high positive direct effect at genotypic (0.292) and phenotypic (0.201) levels. The trait exerted negative indirect effect through plant height, leaf area, percent flowering shoot and fruit length. The trait also showed high positive indirect effect on fruit yield via inflorescence per shoot, percent perfect flower and number of fruits per inflorescence. 
Table 2. Genotypic path coefficient analysis showing direct (bold) and indirect effect of yield contributing characters towards yield.

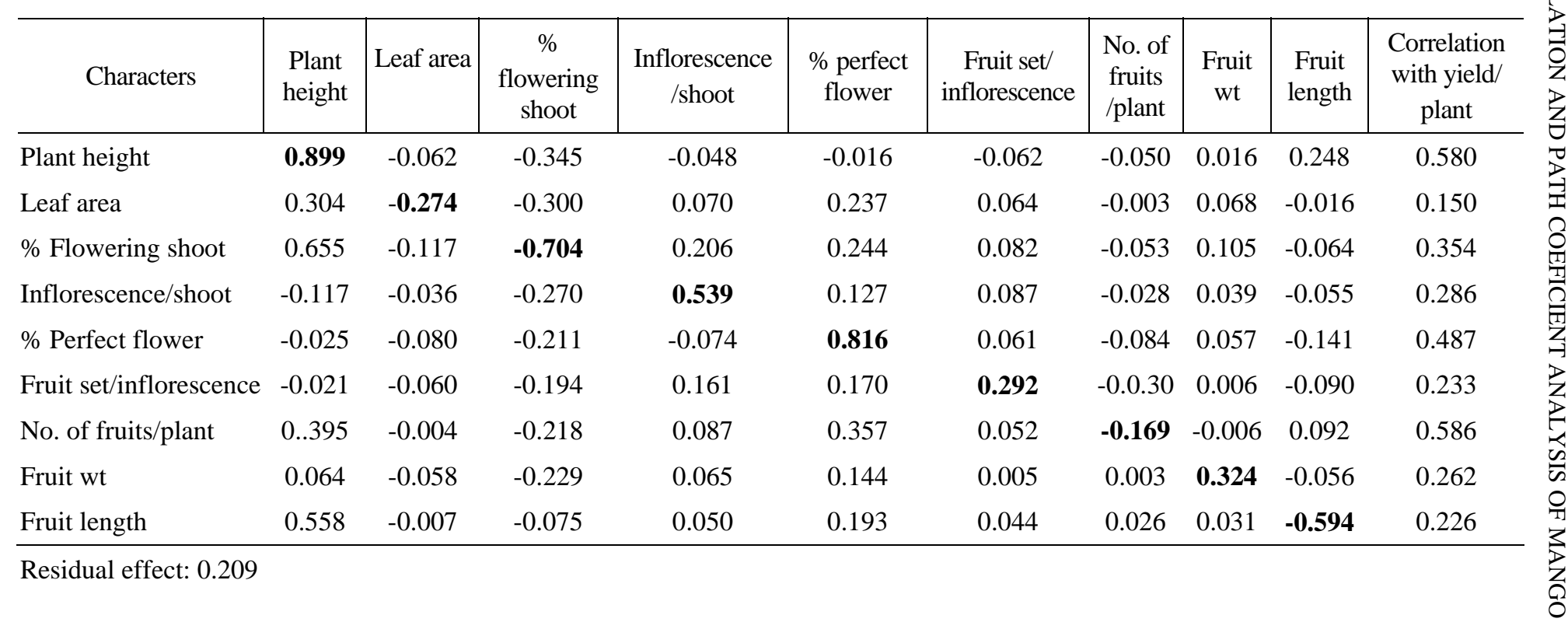


Table 3. Phenotypic path coefficient analysis showing direct (bold) and indirect effect of yield contributing characters

\section{ํํㅇ} towards yield.

\begin{tabular}{l|c|c|c|c|c|c|c|c|c|c}
\hline \multicolumn{1}{c|}{ Characters } & $\begin{array}{c}\text { Plant } \\
\text { height }\end{array}$ & $\begin{array}{c}\text { Leaf } \\
\text { area }\end{array}$ & $\begin{array}{c}\text { Flowering } \\
\text { shoot }\end{array}$ & $\begin{array}{c}\text { Inflorescence/ } \\
\text { shoot }\end{array}$ & $\begin{array}{c}\text { \% } \\
\text { perfect } \\
\text { flower }\end{array}$ & $\begin{array}{c}\text { Fruit set/ } \\
\text { inflorescence }\end{array}$ & $\begin{array}{c}\text { No. of } \\
\text { fruits } \\
\text { /plant }\end{array}$ & $\begin{array}{c}\text { Fruit } \\
\text { wt }\end{array}$ & $\begin{array}{c}\text { Fruit } \\
\text { length }\end{array}$ & $\begin{array}{c}\text { Correlation } \\
\text { with yield/ } \\
\text { plant }\end{array}$ \\
\hline Plant height & $\mathbf{0 . 9 9 8}$ & 0.008 & -0.413 & -0.028 & 0.003 & -0.003 & 0.064 & 0.013 & -0.044 & 0.598 \\
Leaf area & 0.196 & $\mathbf{0 . 0 1 0}$ & -0.243 & 0.036 & 0.083 & 0.031 & 0.002 & 0.038 & -0.010 & 0.143 \\
\% Flowering shoot & 0.588 & 0.004 & $\mathbf{- 0 . 7 0 5}$ & 0.154 & 0.097 & 0.051 & 0.071 & 0.084 & -0.009 & 0.335 \\
Inflorescence/shoot & -0.067 & 0.001 & -0.261 & $\mathbf{0 . 4 1 8}$ & 0.058 & 0.055 & 0.042 & 0.033 & -0.007 & 0.272 \\
\% perfect flower & 0.003 & 0.002 & -0.182 & 0.065 & $\mathbf{0 . 3 7 7}$ & 0.036 & 0.086 & 0.044 & -0.031 & 0.400 \\
Fruit set/inflorescence & -0.013 & 0.002 & -0.180 & 0.114 & 0.067 & $\mathbf{0 . 2 0 1}$ & 0.040 & 0.004 & -0.019 & 0.216 \\
No. of fruits/plant & 0.250 & 0.000 & -0.195 & 0.069 & 0.128 & 0.031 & $\mathbf{0 . 2 5 5}$ & -0.005 & 0.018 & 0.551 \\
Fruit wt & 0.045 & 0.001 & -0.201 & 0.047 & 0.057 & 0.003 & -0.004 & $\mathbf{0 . 2 9 4}$ & -0.014 & 0.228 \\
Fruit length & 0.269 & -.001 & -0.037 & 0.019 & 0.072 & 0.024 & -0.029 & 0.025 & $\mathbf{- 0 . 1 6 3}$ & 0.179 \\
\hline
\end{tabular}

Residual effect: 0.384 
Number of fruits per plant had negative direct effect on yield per plant at genotypic (0.169) but positive at phenotypic (0.255) levels. This trait exhibited highly positive indirect effect through plant height, inflorescence per shoot, percent perfect flower and percent initial fruit set per inflorescence. It showed negligible negative indirect effect on yield via leaf area, fruit weight and fruit length and highly negative indirect effect through percent flowering shoot.

Path coefficient analysis revealed highly positive direct effect of fruit weight at genotypic (0.324) and phenotypic (0.294) level on yield. The character fruit length revealed that it had negative direct effect on fruit yield both at genotypic and phenotypic level. But it had highly positive indirect effects on yield through plant height, inflorescence per shoot, percent perfect flower and percent initial fruit set per inflorescence at both genetic and phenotypic level. Other indirect effects were of lower magnitude (Table 2 and 3).

\section{Discussion}

The results of correlation studies between yield and yield contributing characters revealed that the genotypic correlation coefficient values were greater than corresponding phenotypic ones for most of the characters under study indicated strong inherent relationship among them. These findings are in close agreement with the findings of Ahmed (2005) and Rahman (2006). From correlation studies, it was observed that plant height, percent flowering shoot, inflorescence per shoot, percent perfect flower, and number of fruits per plant were significantly and positively correlated with yield of mango both genotypically and phenotypically. On the contrary, Saha (2004) found insignificant positive correlation of plant height and diameter of fruit on yield. Jahan (2004) also observed insignificant positive correlation of plant height and diameter of fruit with yield in lime. Torres et al. (1986) reported negative association of fruit diameter and yield in case of Valencia orange. However, Ahmed (2005) reported significant and positive association of fruit circumference and yield per plant in lime.

On the other hand, leaf area, length of fruit, weight of fruit and percent initial fruit set per inflorescence were positively correlated with yield but all were insignificant. Saha (2004) reported similar results except leaf area. In case of lime, same findings were reported by Jahan (2004) for leaf area and fruit length but significant positive correlation was observed between fruit weight and yield of lime. Hittalmani and Rao (1976) reported positive correlation between seed number and fruit weight of kagzi lime fruit. Rahman (2006) also found significant positive correlation between fruit weight and yield. Ahmed (2005) observed significant positive correlation of leaf area, fruit length, and average fruit weight in lime. 
Highly significant positive correlation was revealed between percent perfect flower and yield, which indicated strong association of two characters. Thus, if percent perfect flower increases the yield will also increase. The magnitude of correlation between number of fruits per plant and yield was significantly higher both at genotypic (0.487) and phenotypic (0.400) level. Correlation between percent perfect flower and number of fruits per plant was highly positive and significant. Thus, an increase of percent perfect flower and number of fruits accompanies increase in yield per plant. These findings are in agreement with the findings of Chakrawar and Jathure (1980). Highest significant positive correlation was revealed between plant height and yield, which indicated strong association of these characters.

In genotypic path analysis, plant height had the highest positive direct effect (0.899) on yield of mango. Higher positive direct effects were also observed for the characters inflorescence per shoot (0.539), percent perfect flower (0.816), and percent initial fruit set (0.292), and fruit weight (0.324).

Leaf area, percent flowering shoot, number of fruits per plant and fruit length showed negative direct effects towards yield. In phenotypic path analysis, except percent flowering shoot per plant and fruit length, other characters also exhibited similar trend on yield as genotypic path coefficient. Thus, it was distinct that plant height, inflorescence per shoot, percent perfect flower, percent initial fruit set per inflorescence and fruit weight are the major component of fruit yield in mango. In addition, percent flowering shoot, number of fruits per plant and leaf area had considerable contribution towards yield. Percent perfect flower exerted higher positive indirect effect on yield through number of fruits per plant. Rahman (2006) reported maximum positive direct effect of percent fruit set on yield in lime. Saha (2004) found maximum positive direct effect for average weight of fruit on yield in lemon.

Therefore, from the study of genetic association we observed that the characters like plant height, inflorescence per shoot, percent perfect flower, fruit set per inflorescence, number of fruits per plant and fruit weight had the significant positive direct effect on yield, which indicates the selection of these traits would give better response in yield. But leaf area, percent flowering shoot and fruit lengths were negatively related among them. That means simultaneous selection for the characters might be effective in the improvement of fruit yield.

Residual effect indicates the contribution of other factors on the variability than the studied ones. Therefore, the present studies indicated that plant height; individual fruit weight and percent perfect flower had positive direct effect on fruit yield per plant. So, emphasis should be given to selection of these characters for the improvement of yield in mango. 


\section{Acknowledgement}

The authors are grateful to the authorities of Germplasm Centre, Fruit Tree Improvement Program (FTIP) project funded by SDC for providing materials and necessary facilities to conduct the experiments.

\section{References}

Ahmed, I. U. 2005. Morphological and molecular characterization of some lime germplasm. M. S. Thesis. Dept. of Plant Breeding and Genetics, Bangladesh Agricultural University, Mymensingh. 119p.

Bhatt, G. M. 1973. Significance of path co-efficient analysis determining the nature of character association. Euphytica 22: 338-343.

Chakrawar, V. R. and S. D. Jathure. 1980. Correlation studies on Kagzi limes strains. Punjab Hort. J. 20: 39-40.

Desai, U. T., A. M. Musade, S. A. Ranpise, S. M. Choudhari and P. N. Kale. 1994. Correlation studies in acid lime. J. Maharashtra Agric. Univ. 19(1): 162-163.

Dewey, D.K. and L.H., Lu. 1959. A correlation and path co-efficient analysis of components of creased wheat grass and production. Agron. J. 51: 515- 518.

Grafius, J.E. 1959. Heterosis in barely . Agron. J. 51: 551-554.

Hittalmani, S. V. and M. M. Rao. 1976. Studies on changes in physical parameters of the developing Kagzi lime fruit. South Indian Hort. 24 (4): 122-126.

Hohenboken, W.D.1985. Phenotypic, genetic and environmental correlations. In: general and Quantitative Genetics. Chapman A.B. (ed). Elsevier Science Publishers, B.V.Amsterdam.pp.121-134.

Jahan, A. 2004. Study on characterization of lime using morphological traits and peroxidase isozyme. M. S. thesis. Dept. of Plant Breeding and Genetics, Bangladesh Agricultural University, Mymensingh. 120p.

Prasad, M. B. N. V. and G. S. P. Rao. 1989. Genetic variability, correlations and pathcoefficient analysis for some morphological and biochemical constituents of acid lime fruit. Scientia Hort. 41: 43-53.

Rahman, M. M. 2006. Characterization of lime using morphological traits and RAPD. M.S. thesis, Dept. of Horticulture, Bangladesh Agricultural University, Mymensingh, Bangladesh. 103p.

Rao, E.S., A.D. Munshi and V.K. Verma.2004. Genetic association and interrelationship of yield and its components in cucumber (Cucumus sativus L.). Ind. J. of Hort. 63 (4): 402-406.

Saha, P. 2004. Performance of some lemon germplasm and their morphological and molecular characterization using isozyme. M. S. Thesis. Dept. of Plant Breeding and Genetics, Bangladesh Agricultural University, Mymensingh, Bangladesh. 119p.

Singh, R.K. and B.D. Chaudhury. 1985. Biometrical Methods of Quantitative Genetic Analysis. Harayana J. Hort. Sci. 12(1):151-156.

Torres, O. M., A. Rodriguez and M. A. Santos. 1986. Study of the diameter and diameter length relationship of fruit in different lines of Valencia orange (Citrus sinensis). Ciencia-Y-Technica-en-la-Agricultura, Citrocos-Y-others- Frutales, 9(3): 107-114 [Cited from CAB Abst., Vol. CIAC, 1987-1989].

Wright, S. 1921. Correlation and causation. J. Agric. Res. 20: 257-287. 